\title{
GALVINIEKA UN ĶİLAS DEVĒJA REGRESA TIESĪBU REGULĒJUMS LATVIJAS CIVILTIESĪBĀS
}

\section{RIGHTS OF RECOURSE OF SURETIES AND SECURITY PROVIDERS IN LATVIAN CIVIL LAW}

\author{
Aleksandrs Fillers, Dr. iur., LL.M
}

Rīgas Juridiskās augstskolas docents

\section{Summary}

The Latvian Civil Law allows a person to provide security rights in movable and immovable assets to secure a debt of another person. However, the Civil Law does not give any guidance on the security provider's rights of recourse against the principal debtor, once the creditor obtains satisfaction of his/her claims from the encumbered asset. The Latvian Supreme Court has ruled that, in fact, the security provider has no rights of recourse. The author opposes this approach, arguing that the security provider must have a right of recourse that should be construed using an analogy of the rights of recourse granted to the surety. This approach is justified by the striking similarity between a third-party security provider and a surety.

Atslēgvārdi: galvojums, regresa tiesības, ķīlas tiesības, subrogācija

Keywords: suretyship, rights of recourse, pledge, subrogation

\section{Ievads}

Civillikuma (turpmāk - CL) normas par k̦īlas tiesībām pietiekami skaidri nenodala gadījumus: 1) kad parādnieks ieḳīlā savu lietu un 2) kad lietu par svešu parādu ieḳīā trešā persona. Taču šie gadījumi prasa atškîingu regulējumu. Tieši pēdējā gadījumā rodas pamatots jautājums, kādas ir ḳilas devēja tiesības pēc tam, kad ķīlas objekts ir ticis pārdots un no šì darījuma ieņemtā summa ir izmantota, lai pilnībā vai dal̦ēii nolīdzinātu nodrošināto prasījumu?

Šis jautājums ir aktualizējies sakarā ar Augstākās tiesas spriedumu, kurā tā norādīja, ka "[g]alvojumā galvinieks pilda akcesoru saistību, kas l̦auj izlietot regresa prasību, turpretim k̦īlas devējam Civillikums neparedz tiesības vērst regresa prasību pret galveno parādnieku". ' Šì Augstākās tiesas tēze dod pamatu vispusīgāk apskatīt jautājumu par ķīlas devēja tiesībām uz regresa tiesībām.

Saskaṇā ar CL 1704. pantu, kādā apmērā galvinieks apmierina kreditoru, tādā uz viṇu pāriet šà pēdējā prasījumi pret galveno parādnieku. Taču CL nevar atrast analoǵisku normu gadījumam, kad ķīla tiek dota sveša parāda

1 Augstākās tiesas 05.06.2017. spriedums lietā Nr. SKC-76/2017. Pieejams: http://at.gov.lv/downloadlawfile/5160 [aplūkots 10.03.2020.]. 
nodrošināšanai. CL klusēšana dod pamatu jautājumam, vai k̦īlas devējam ir regresa tiesības pret parādnieku? Lai atbildētu uz šo jautājumu, sākumā ir jāizvērtē, ko CL saprot ar galvinieka regresa tiesībām.

\section{Galvinieka divi regresa prasījumi}

Kā jau minēts, CL 1704. pantā ir paredzēts, ka galviniekam ir regresa prasība pret galveno parādnieku. Proti, CL 1704. pants noteic: "kādā apmērā galvinieks apmierina kreditoru, tādā uz viṇu pāriet šā pēdējā prasījumi pret galveno parādnieku. Prasības un ierunas no tās tiesiskās attiecības, kas pastāv starp galvinieku un galveno parādnieku, paliek negrozìtas”. CL 1704. pantā nav lietots termins "regress", bet jau CL 1705. pantā ir teikts, ka "galvinieks var vērst savu regresa prasību [..]". ${ }^{2}$ Tātad ir acīmredzami, ka CL 1704. pantā ir runa par tādu civiltiesisku mehānismu, kas citās normās apzīmēts kā "regresa prasība". CL 1704. panta pirmā teikuma nozīme tiek skaidrota doktrīnā: tajā ir runa par subrogāciju (cessio legis), ${ }^{3}$ proti, automātisku kreditora prasijuma pāreju uz galvinieku. ${ }^{4}$

Taču par ko ir runa CL 1704. panta otrajā teikumā? Andris Grūtups savulaik norādīja, ka CL 1704. panta otrajā teikumā "ar jēdzienu "no tās tiesiskās attiecības” [esot] jāsaprot galvenā parāda saistība ar visām no tās izrietošām un ar to saistītām tiesībām, kurā nešaubīgi ietilpst[ot] arī ķīlas tiesība, ja tā kalpojusi par nodrošinājumu galvenajai parāda saistībai" ${ }^{5}$ Tomēr viņš nebija ñēmis vērā, ka CL 1704. panta otrajā teikumā ir runa nevis par tiesisko attiecību starp kreditoru un galveno parādnieku, bet starp galvinieku un galveno parādnieku. Proti, starp galvinieku un galveno parādnieku pastāv vēl kāda cita tiesiskā attiecība, kas var radìt prasijumus un ierunas.

Šādas tiesiskās attiecības bija zināmas jau romiešu tiesībās. Pirmkārt, galvinieks var galvot, parādniekam nezinot, un tādā gadījumā viṇam būs prasījums no neuzdotas lietvedības. Otrkārt, parādnieks var lūgt kādu personu par viṇu galvot, tādā gadījumā galviniekam būs prasījums no pilnvarojuma līguma. Abos gadijjumos galvinieks var atprasīt izmaksāto summu kā savus izdevumus, kas ir nākuši par labu parādniekam, ja visi pārējie priekšnoteikumi prasījumam no neuzdotas lietvedības/pilnvarojuma līguma ir izpildìti. ${ }^{6}$ Tieši šie divi prasījumi sākotnēji l̦āva galviniekam atgūt to, ko viņš bija samaksājis kreditoram; vēl pirms romiešu tiesībās tika attīstīts īpašs subrogācijas mehānisms. ${ }^{7}$

2 Termini "regresa prasība" un "regresa tiesība" tiek minēti arī citās normās, kas attiecas uz galvojumu: CL 1706., 1708., 1709. un 1711. pants.

3 Turpmāk šajā rakstā autors izmantos tieši terminu "subrogācija”, lai apzīmētu automātisku prasījuma pāreju no kreditora galviniekam, proti, kā sinonīmu "likumiskai cesijai". Raksta ierobežotais apjoms neḷauj apskatīt plašāk jēdziena "subrogācija" lietojumu citās tiesību sistēmās.

4 Latvijas Republikas Civillikuma komentāri. Saistību tiesības (1401.-2400. p.). Autoru kolektīvs prof. K. Torgāna vispārīgā zinātniskā redakcijā. Rīga: Mans Īpašums, 1998, 207.-208. lpp.

5 Ibid., 208. lpp.

6 Piemēram, CL 2331. pants paredz, ka persona, kas ved svešas lietas, kuras tai vest bija noteikti aizliegts, nevar prasīt izdevumu atlīdzināšanu. Šì norma ir attiecināma arī uz galvojumu, kas dots pretēji parādnieka aizliegumam. Zimmermann R. The Law of Obligations: Roman Foundations of the Civilian Tradition. Cape Town: Juta \& Co, Ltd, 1992, pp. 133-134.

7 Ibid. 
Šādu CL 1704. panta izpratni netieši apstiprina arī citi apsvērumi. Baltijas vietējo likumu kopojums (turpmāk - BVLK) paredzēja divu veidu tiesības galviniekam sakarā ar parāda nomaksu. Pirmkārt, BVLK 4531. pants paredzēja tā saucamo piespiedu cesiju jeb galvinieka tiesības nepildìt savu saistïbu, pirms kreditors nebija piekritis līgumiskai cesija. ${ }^{8}$ Taču, ja reiz galvinieks bija samaksājis, nesaṇemot šādu piekrišanu, tad viņš "nepārṇēma" kreditora prasijumus. ${ }^{9}$ Savukārt BVLK 4537. pants paredzēja, ka neatkarīgi no cesijas galviniekam bija tiesības prasīt no galvenā parādnieka atlìdzināt viņam samaksāto parādu. Interpretējot BVLK 4537. pantu, Karls Erdmans (Carl Erdmann) norādīja, ka tajā esot piešķirtas tiesības, kas nav tieši pamatotas ar tiesiskajām attiecībām starp galvinieku un galveno parādnieku. ${ }^{10}$ Šāds secinājums ir kḷūdains. Izpētot BVLK 4537. panta romiešu tiesību avotus, var skaidri redzēt, ka tie atsaucās tieši uz pilnvarojumu vai neuzdoto lietvedību kā prasijumu pamatiem. ${ }^{11}$

Galvinieka regresa tiesības CL 1704. pantā ir būtiski modernizētas salīdzinājumā ar BVLK, pirmkārt, jau ar pāreju uz subrogācijas modeli. CL 1704. pants būtiski līdzinās Šveices Saistību tiesību kodeksa 507. panta pirmajai un trešajai daļai. 507. panta pirmajā dạ̦ā ir noteikts, ka "galvinieks iestājas kreditora tiesībās tādā apmērā, kādā tas ir to apmierinājis [...]". ${ }^{12}$ Savukārt tā paša panta trešajā dạ̧ā ir noteikts, ka "ipaši prasijumi un ierunas, kas izriet no tiesiskās attiecības starp galvinieku un galveno parādnieku, tiek saglabātas". Šveices tiesību literatūrā norādīts, ka saskaņā ar 507. pantu galviniekam ir divi paralēli regresa veidi: 1) subrogācijas regress - galvinieks pārṇem kreditora prasijumu uz likuma pamata (to dēvē arī par "vispārīgo regresu"); 2) prasijums, kas izriet no tās tiesiskās attiecības, kas pastāv starp galvinieku un parādnieku (to dēvē arī par "speciālo regresu"), kas parasti ir pilnvarojuma līgums vai neuzdota

${ }^{8}$ Līdzīgu terminologiju lietoja Aleksandrs Būmanis. Sk.: Būmanis A. Galvojums civiltiesībās. [B. v.]: [B. i.], 1933, 157. lpp.

9 Буковскій В.Сводъ гражданских узаконеній губерній Прибалтийских. Томъ II. Рига: Типография Г. Гемпель и Ко, 1914, с. 2002. Šāds regulējums bija saistīts ar tīri tehnisku apsvērumu: ja prasījums bija izpildīts, tad tas bija izbeidzies un tā pāreja vairs nebija iespējama - nebija pārejas objekta. Sk.: Zimmermann R. 1992, p. 134.

10 Эрдман К. Обязательственное Право Губерній Прибалтійскихъ. Рига: Изданіе почетного мирового судьи Ф. Э. Камкина, 1908, с. 548. Sk. arī: Буковскій В. 1914, с. 2004.

11 BVLK 4537. panta avoti ir atrodami: Нолькен А. М. Свод гражданских узаконений губерний Прибалтийских (Часть III). Петроград: Издание Юридического книжного склада “Право”, 1915, c. 877. Viens no šiem avotiem ir Ulpiāna (Ulpianus) digesta, kas angḷu valodas tulkojumā skan šādi: "A surety can be taken in an action on mandate, or in one for business transacted, which I am about to bring against the person for whom I became surety." Sk.: The Enactments of Justinian. The Digest or Pandects. Book XLVI. Pieejams: https://droitromain.univ-grenoble-alpes.fr/Anglica/D46_Scott.htm [aplūkots 10.03.2020.]. Salīdzinot angḷu valodas versiju ar latīṇu valodas oriǵinālu, kḷūst skaidrs, ka termins “business transacted" apzīmē neuzdotu lietvedību. Minētā digesta liecina, ka BVLK 4537. pants neradīja patstāvīgu regresa mehānismu, bet tikai apstiprināja tiesības uz izdevumu atlīdzināšanu no pilnvarojuma liguma/neuzdotas lietvedibas.

12 Sk.: Šveices Saistību tiesību kodeksa tulkojums anglu valodā: 1) 507. panta pirmā daḷa: “The surety is subrogated to the creditor's rights to the extent that he has satisfied him. The surety may exercise these as soon as the obligation falls due." 2) 507. panta trešã daḷa: "Special claims and defences arising from the legal relationship between the surety and the principal debtor are reserved." Pieejams: https://www. admin.ch/opc/en/classified-compilation/19110009/202001010000/220.pdf [aplūkots 10.03.2020.]. 
lietvedība. ${ }^{13}$ Jānorāda, ka šāds risinājums pastāv arī Francijā, Vācijā, Austrijā un citās valstīs. ${ }^{14}$

Ir vērts īpaši uzsvērt, ka Šveices tiesības tika uzskatītas par būtisku avotu, sastādot CL. ${ }^{15}$ Tāpēc ir pamats hipotēzei, ka tieši Šveices saistību tiesību kodeksa 507. pants varēja noderēt par iedvesmu CL 1704. panta formulējumam. Tas dotu vēl papildu argumentu apgalvojumam, ka CL 1704. pants l̦auj galviniekam saṇemt atlīdzinājumu no parādnieka uz diviem pamatiem: subrogācijas un prasījuma no konkrētās tiesiskās attiecības.

Lìdz ar to autora secinājums ir tāds, ka CL 1704. pants l̦auj galviniekam izvēlēties vienu no diviem prasījumiem. Pirmkārt, galvinieks var izvirzìt to pašu prasījumu, kas bija kreditoram pirms samaksas. Otrkārt, viņš var izvēlēties arī izvirzīt prasījumu par izdevumu atlīdzināšanu, kas parasti būs pamatots vai nu ar pilnvarojuma lìgumu, vai arī ar neuzdotu lietvedību. No CL terminologijas izriet, ka abi šie prasījumi tiek apzīmēti kā regresa prasība jeb regresa tiesība.

\section{Liettiesiskā galvinieka (ḳilas devēja) regresa tiesības}

Kā jau minēts iepriekš, ķīlu var dot gan pats parādnieks, gan arī trešā persona. CL expressis verbis l̦auj trešajai personai dot k,īlu, ${ }^{16}$ taču faktiski nesatur normas, kas specifiski regulētu šādu ḳillas veidu. Jānis Rozenfelds ir norādījis, ka "[k] īlas nodibināšanai par labu citas personas uzn,emtai saistībai ir liettiesiska galvojuma raksturs, t. i., tāds galvojums, kas aprobežojas tikai ar ieḳilātās mantas apjomu [..]" ${ }^{17}$ Šis ir l̦oti trāpīgs raksturojums, un tam ir praktiskas sekas.

Būtiska līdzība starp galvojuma un ķīlas institūtu (ja ķîlu dod trešā persona) neizbēgami noved pie galvinieka un ḳīlas devēja tiesisko statusu pielīdzināšanas. Proti, galvinieks apṇemas nodrošināt citas personas parādu, tādā veidā sekmējot civiltiesisko apgrozību un atvieglojot kredita pieejamību. Liettiesiskais galvinieks dara tieši to pašu: vinšs dod savu mantu ḳilā un uzṇemas risku, ka attiecīgā manta tiks atsavināta un ieguvumi no atsavināšanas nonāks kreditora mantā, tādējādi sedzot parādnieka saistību. Vēl jo vairāk, kā ir norādījis Aigars Strupišs, "hipotēka tiek uzskatīta par visdrošāko prasības nodrošinājuma līdzekli privāttiesībās. [..] Līdz ar to jebkura iespēja padarìt hipotēkas institūtu mazāk drošu [nozìmē] būtisku tiesiskās drošības principa nozīmes samazināšanu privāttiesību sistēmā un kopumā negatìvu ietekmi uz privāttiesisko apgrozību valstî”. ${ }^{18}$ Tādējādi, ja jau likumdevējs ir vēlējies veicināt galvojumu došanu, sniedzot viņam iespēju vērst regresa prasījumu pret galveno parādnieku uz diviem alternatīviem pamatiem, tad šādas privilēgijas a fortiori ir pieškiramas liettiesiskam galviniekam.

13 Thévenoz L., Werro F. (ed.). Commentaire Romand: Code des obligations I. Bâle: Helbing, 2012, p. 3014.

14 Sk.: Principles, Definitions and Model Rules of European Private Law Draft Common Frame of Reference (DCFR), pp. 2660-2664 (komentārs IV.G.-2:113. pantam). Pieejams: https://www.law.kuleuven. be/personal/mstorme/european-private-law_en.pdf [aplūkots 10.03.2020.].

15 Švarcs F. Civillikums un tā rašanās vēsture. Rīga: Tiesu namu aǵentūra, 2011, 164. lpp.

16 CL 1306. panta otrā daḷ.

17 Rozenfelds J. Lietu tiesības. Rìga: Zvaigzne ABC, 2011, 174. lpp.

18 Satversmes tiesas 07.10.2013. lēmums lietā Nr. 2012-25-01. Pieejams: https://likumi.lv/ta/id/260763par-tiesvedibas-izbeigsanu-lieta-nr-2012-25-01 [aplūkots 10.03.2020.]. 
Turklāt atškirīibā no "personiskā" galvojuma ${ }^{19}$ CL 1319. un 1320. pants nepiešķir ķillas devējam "subsidiaritātes" ierunu, proti, kreditors var vērst piedziņu pret iekiilāto mantu, lai arī tas nemaz nav mēóginājis saņemt parāda apmierinājumu no parādnieka. Līdz ar to "personiskā" galvojuma gadījumā bieži galvinieka atbildība būs subsidiāra un iestāsies tikai tad, kad galvenais parādnieks objektīvi nebūs spējīgs saistîbu izpildìt. Šajā gadījumā arī regresa prasỉjumiem būs salīdzinoši maza praktiska nozīme, jo no šāda parādnieka arī galviniekam būs grūti iegūt apmierinājumu. Turpretim "liettiesiska" galvojuma gadījumā regresa tiesībām var būt lielāka loma tajā, lai maksātspējīgs parādnieks neiedzīvotos uz ķīlas devēja rēķina.

N̦emot vērā minētos apstākḷus, būtu pamatots uzskats, ka CL 1704. pants visā tā pilnībā ir mutatis mutandis pēc analog̣ijas piemērojams arī "liettiesiskā galvojuma” gadījumā. Citiem vārdiem, ķīlas devējam ir jābūt iespējai izmantot divu veidu regresa prasijumus: vienu subrogācijas cel̦ā un otru, pamatojoties uz to tiesisko attiecību, kas pastāv starp kīlas devēju un parādnieku. Šāda CL normu piemērošana pēc analoǵijas būtu teleoloǵiski pamatota; to stiprina arī tas apstāklis, ka citās kontinentālās Eiropas valstīs galvinieka regresa tiesības tiek piemērotas pèc analogijas k̦ìlas devējam. ${ }^{20}$ Arī Kopējais modelis (Common Frame of Reference) norāda, ka ḳilas devēja tiesības ir identiskas galvinieka tiesībām. ${ }^{21}$ Latvijas tiesām būtu jāiztulko CL normas saskaņā ar to mērḳiem un arī pēc iespējas ñemot vērā citu vadošo jurisdikciju pieredzi.

Tomèr arī neatkarīgi no CL 1704. panta piemērošanas pèc analoǵijas ķīlas devējam būtu tiesības uz "personisko" regresu, ja viṇa rīcība atbilstu priekšnoteikumiem prasijumam no neuzdotas lietvedibas vai pilnvarojuma lïguma. Kādēḷ? Tāpēc, ka neatkarīgi no CL 1704. panta piemērošanas CL nav atrodamas normas, kas noteiktu, ka ḳilas devējam nebūtu tiesību saņemt izdevumu atlīdzināšanu kā pilnvarniekam vai svešu lietu lietvedim. Tātad šādas tiesības viṇam pastāv. Lìdz ar to pretēji Augstākās tiesas tēzei, kas ir minēta šì raksta sākumā, ķīlas devējam principā ir regresa tiesības CL 1704. un 1705. panta izpratnē pat tad, ja tiktu pieņemts (nepamatoti), ka pats CL 1704. pants nav attiecināms uz ķīlas devēju pēc analoğijas.

Šajā vietā ir svarīgi norādīt uz vienu iespējamo pretargumentu. CL 1797. pants noteic: "kas apmierina kreditoru parādnieka vietā, tam pirms apmierinājuma vai apmierinājuma laikā jāpielīgst, lai kreditors viṇam cedē prasijumu, un ja tas izdarìts, tad prasijums pats par sevi uzskatāms par cedētu viñam apmierinājuma brīdī”. Piemērojot šo normu, varētu veidot sekojošu argumentu ķēdi: ja kreditors vērš prasijumu pret ķīlas devēja (trešās personas) lietu un tādējādi panāk prasījuma apmierinājumu, tad ḳilas devējs ir pielīdzināms trešajai personai, kas ir apmierinājusi kreditoru parādnieka vietā. Tātad, lai šādam

\footnotetext{
19 CL 1702. pants.

20 Šāds risinājums pastāv Francijā. Sk.: Bourassin M., Brémond V., Jobard-Bachellier M.-N. Droit des sûretés. Paris: Dalloz, 2012, p. 627. Vācijas Civillikuma (BGB) 1143. pantā ir noteikts, ka ḳilas īpašnieks, kurš nav parādnieks, iegūst tādas pašas regresa tiesības kā galvinieks, ja viņš sedz parādnieka parādu. Pēc analogijas šì norma tiek piemērota arī gadījumā, kad kreditors vērš prasību pret ieḳilāto lietu un no tās iegūst apmierinājumu. Sk.: Stürner R. (Hrsg.). Jauernig BGB: Bürgerliches Gesetzbuch. München: C. H. Beck, 2018, 1143. \$ komentārs, 1. rindkopa.

${ }^{21}$ Principles, Definitions and Model Rules of European Private Law Draft Common Frame of Reference (DCFR), p. 4705 (komentārs IX.-7:109. pantam). Pieejams: https://www.law.kuleuven.be/personal/ mstorme/european-private-law_en.pdf [aplūkots 10.03.2020.].
} 
ķilas devējam būtu kāda regresa tiesỉba, viņam ir jāpanāk prasījuma brīvprātīga cesija. ${ }^{22}$

Šāda argumentu ḳēde ir atspēkojama. CL 1797. pants atbilst BVLK 3466. pantam. BVLK 3466. panta romiešu tiesību avoti norāda, ka tajā bija runa tieši par automātiskās subrogācijas neiespējamību, ko pamatoja tehniski apsvērumi. Proti, romiešu jurists Modestīns (Herennius Modestinus) apgalvoja: ja kāds nomaksā cita parādu, tad ar to parāds tiek dzēsts, un, ja tas netiek iepriekš cedēts (faktiski izpirkts), tad tā maksātājam nav prasỉjuma tiesības, jo tā ir dzēsta. ${ }^{23}$ BVLK 3466. panta avoti nenorāda, ka šie tīri tehniskie apsvērumi kaut kādā veidā ietekmētu trešās personas prasijumus, kuru pamatā ir pilnvarojuma līgums vai neuzdota lietvedība. Uz CL 1797. panta tehnisko dabu norāda arī tā atrašanās vieta CL sistēmā. CL 1797. pants ir ievietots nodạ̣ā par "Cesijas tiesisko pamatu". Šādas normas nevar atrast CL nodaḷās par pilnvarojuma līgumu vai neuzdotu lietvedību, un tieši šìm normām visbiežāk ir nozīme gadỉjumos, kad persona veic maksājumu citas personas interesēs. Piemēram, blakus esoša nekustamā īpašuma īpašnieks samaksā sava kaimiņa vietā par viņam piegādāto malku, lai novērstu kaimiņa praktiskos riskus (piemēram, risku palikt bez kurināmā) un tiesiskos riskus (nokavējumu). Šāds maksātājs neiegūst kreditora prasijumu uz subrogācijas pamata, bet viñam noteikti būs tiesības uz izdevumu atlīdzināšanu saskanāa ar CL 2339. pantu. To apstiprina arī CL 2341. pants, kurā ir noteikts, ka tas, "kas, domādams samaksāt savu parādu, samaksā svešu, tas var, pēc sava ieskata, vai nu prasìt atpakaḷ no saṇēmēja tam samaksāto neesošo parādu, vai kā istā parādnieka lietvedis griezties pie tā ar prasijumu”. Šì norma tikai precizē, ka trešā persona, kas maldīgi nomaksā citas personas parādu, iegūst divus alternatīvus prasījumus: vienu pret naudas saņēmēju un citu pret ìsto parādnieku. A contrario, tam, kas apzināti samaksājis svešu parādu, var būt tikai prasījums pret parādnieku - kā tā lietvedim.

No iepriekšminētā var izdarìt sekojošus secinājumus. Pirmkārt, autora skatījumā CL normu logiika un mērki pamato CL 1704. panta piemērošanu pēc analogiijas kīlas devējam. Otrkārt, arī gadījumā, ja tiktu uzskatìts, ka CL 1704. pants nav piemērojams ķīlas devējam, tad ķīlas devējam būtu regresa prasijjums no personiskām attiecībām ar parādnieku, kas parasti būtu balstìts uz pilnvarojuma ligumu vai neuzdotu lietvedību.

${ }^{22}$ Te gan ir jāatzīmē, ka CL 1797. panta piemērošana šajā gadījumā varētu radīt grūtības. Ja kreditors cedē prasījumu k̦īlas devējam, tad prasījums vairs nepieder kreditoram. Tad uz kāda pamata viņš varēs meklēt apmierinājumu no ķīlas objekta? Savukārt, ja kreditors jau ir apmierinājis savu prasījumu, atsavinot lietu, tad prasījums jau ir izbeidzies (vismaz daḷā) un to nevar cedēt. Šo problēmu var atrisināt, tieši piemērojot pēc analogijas CL 1704. panta pirmo teikumu.

23 BVLK 3466. panta avotus sk.: Нолькен A. M. 1915, c. 659. Galvenais avots bija šāda Modestīna digesta: "[..] payment having been made of everything that was due on a tutelary account without any agreement, if, after a certain interval, the rights of action are assigned, the assignment is void, because no such right remains. If, however, this was done before payment, or if it was agreed between the parties that the rights of action should be assigned, and payment is made, and the assignment afterwards takes place, the rights of action will remain unimpaired; as, even in the last instance, the price of those which were assigned seems rather to have been paid than that the right which existed at the time has been extinguished." The Enactments of Justinian. The Digest or Pandects. Book XLVI. Pieejams: https:// droitromain.univ-grenoble-alpes.fr/Anglica/D46_Scott.htm [aplūkots 10.03.2020.]. 


\section{Kopsavilkums}

1. Galvinieka regresa prasība aptver divus dažādus prasijumus: prasijumu, ko galvinieks iegūst subrogācijas cẹ̦ā, un prasījumu, kas galviniekam pieder saskaņā ar to civiltiesisko attiecību, kas pastāv starp viņu un galveno parādnieku.

2. Kî̀las devējam, tāpat kā galviniekam, ir regresa prasijums pret parādnieku saskañā ar to civiltiesisko attiecību, kas pastāv starp vinu un parādnieku. Parasti šāds regresa prasijums izrietēs no pilnvarojuma līguma vai neuzdotas lietvedības. Jau šì iemesla dēḷ nevar piekrist Augstākās tiesas praksei, kurā tā ir pretstatījusi galvojuma un ķīlas institūtu, uzsverot, ka pēdējais neparedz regresa prasibu pret parādnieku.

3. Tomēr autora skatījumā ḳīlas devējam, tāpat kā galviniekam, ir jābūt arī prasijumam, kas iegūts subrogācijas cel̦ā. Proti, CL 1704. pants bùtu pilnā mērā mutatis mutandis piemērojams ḳ̂ilas devējam, kas ir devis kịlu par svešu saistību, jo nepastāv saprātīgs izskaidrojums, kādēl persona, kas dod ḳilu par svešu saistību, būtu nostādāma sliktākā stāvoklī par galvinieku. 